\title{
Chemical Compounds of Thyme as a Medicinal Herb in the Mountainous Areas of Iran
}

\section{Arzani $\mathrm{H}^{1 *}$, Motamedi ${ }^{2}$ and Arzani $^{3}$}

${ }^{1}$ Professor, Faculty of Natural Resources, University of Tehran, Karaj, Iran

${ }^{2}$ Assistance Professor, Faculty of Natural Resources, University of Urmia, Urmia, Iran

${ }^{3}$ Chemistry Teacher, University of Farhangyan, Hakim ferdosy, Karaj, Iran

\begin{abstract}
Information from chemical component of medicine plants help landholders to use their property as multiple use to raise their income for sustainable utilization. Also society will become aware from benefits of range species. In this research chemical component of Thymus species including Thymus kotschyanus, Thymus fedtschenkoi, Thymus daenensis, Thymus transcaspicus was investigated in 7 mountainous regions during three phenological stages of vegetative, flowering and maturity (seeding). Samples were collected from three replicate (5 individual plants for each). Then nitrogen percentage and acid detergent fiber were measured in laboratory to calculate metabolizable energy and protein in terms of animal nutrition. The chemical compounds of essential oil in these spices were evaluated by GC and GC/MS system. According to the results plants are palatable for livestock during vegetative and flowering period and are desirable as medicine during maturity stage. They have essences, alkaloids, tenants, nitrate and glycosides. So they can be used in multiple purpose of grazing and human requirement to raise landholder's income.
\end{abstract}

Keywords: Chemical compound; Medicinal plants; Human nutrition; Animal nutrition

\section{Introduction}

Awareness of chemical compound of rangelands and forest plants with medicinal value is one of the basic necessities of natural ecosystems' versatile use. In recent years, application of medicinal plants has been increased regarding their side effects, lower cost, and patients' compliance to these medications and considering the known side effects of the synthetic drugs.

In Iran, nearly eight thousand plant species grow that most of these plants can have medicinal effects in addition to nutritional value for animals. Different species of the mints (Lamiaceae) family for having special and important pharmaceutical and nutritional characteristics are among the first families that have been identified by botanists [1]. The plants of this species are scattered around the world, but particularly have gathered in the Mediterranean areas [2].

The genus thymus is one of the plants in the family Lamiaceae that contains 250 species in the world and 14 species of this genus are scattered in Iran [2]. Most species of thyme are widely used in different parts of the world as a beverage (tea), food flavors (spices and condiments), and herbal medicine. Moreover, the flowering tops of this plant are used in the form of tea as carminative, food digestive, antispasmodic, antitussive, and expectorant for treating the cold in other parts of Iran [1].

Several studies have been conducted on the chemical compound of thyme and especially its flavor's different compounds in Iran. In Iran, different thyme species generally have $0.8-2.6 \%$ volatile oil (essential oil) that includes very variable amounts of monoterpene hydrocarbons, oxygenated monoterpenes, sesquoie hydrocarbons such as para-cymene, gamma-terpinene, and alcohol that each of them can be the main compound of the flavor. Generally, thymol is the most common and important phenolic compounds of different Thyme species and a small percentage belongs to the carvacrol [3]. In regard to the identification and comparison of the chemical compound of Thyme essential oil, Asgari et al., [4] have collected the aerial parts of the Thymus pubescens species from four different sites in Tehran at two growth stages (flowering and full flowering stages) and reported that there are 25 compounds before the flowering stage and 26 compounds at the flowering stage in the essential oil of this species. Main compounds of this species include carvacrol, thymol, gammaterpinene, para-cymene, borneol and methyl carvacrol. Moreover, Sajjadi and Khatamsaz [5] investigated the essential oil gained from the aerial parts of Thymus daenensis species in various parts of Hamedan province and stated that from among 43 identified compounds, 5 compounds had the highest percentage: thymol (73.9\%), carvacrol (6.7\%), para-cymene (4.6\%), beta-bisabolene (1.5\%), and terpinene-4ol (1.4\%). Furthermore, investigations of existing compounds in the essential oil of Thymus daenensis in four areas of Esfehan province revealed that from 27 identified species 5 of them had the highest percentage: thymol (51.3-78.3\%), para-cymene (2.7-7.6\%), gammaterpinene (2.7-10.1\%), carvacrol (2.0-9.2\%), and beta-caryophyllene (2.4-4.3\%). Another study conducted by Barazande and Bagherzade [6] showed that the essence sample of Semirom area had the highest amount of specific compounds related to the thyme essential while Golpayegan region had the lowest amount of compounds specific to thyme species. Yavari et al., [7] also investigated the chemical compound of Azerbaijan thyme essential oil (Thymus migricus) in different pastures of West Azerbaijan and reported that average yield of essential oil produced by flowering tops of this species is not identical in different areas and the highest amount (1.7\%) belongs to Nazlu area and the lowest amount (1.4\%) is related to the Band area while this amount is at midpoint (1.5\%) in different places of Ghushchi area. As a whole, in the essential oil of the collected species from Ghushchi, Nazlu and Band areas, respectively, 20, 18, and 21 compounds were identified that from these species three compounds of thymol (46.6$70.5 \%)$, gamma-terpinene (6.2-16.7\%), and para-cymene (4.0-6.2\%) were common for the three areas and had a high density that according to the yield of the previously mentioned essential oil and its richness

*Corresponding author: Arzani, Professor, Faculty of Natural Resources University of Tehran, Karaj, Iran, E-mail: harzani@ut.ac.ir

Received May 29, 2013; Accepted August 06, 2013; Published August 08, 2013

Citation: Arzani H, Motamedi, Arzani (2013) Chemical Compounds of Thyme as a Medicinal Herb in the Mountainous Areas of Iran. J Nutr Disorders Ther S12: 003. doi:10.4172/2161-0509.S12-003

Copyright: $\odot 2013$ Arzani $\mathrm{H}$, et al. This is an open-access article distributed under the terms of the Creative Commons Attribution License, which permits unrestricted use, distribution, and reproduction in any medium, provided the original author and source are credited. 
in terms of thymol as a phenolic compound, it is reported that the essential oil sample of Nazlu area from among the samples in the three areas that were studied in West Azerbaijan province can be used for various purposes, especially medicinal applications.

It is obvious that, apart from the essential oil compounds of thyme species, little information is available about the other chemical compounds and especially the percentage of their crude protein and metabolic energy at different growth stages in order to employ the results for multipurpose utilization of pasture and animal food management on the pasture. In this regard, the current study aimed at presenting comprehensive and complete information about the forage quality indices of various thyme species in mountainous regions of Iran as well as identifying the status of the mentioned values in regard to their critical level for getting informed about meeting the daily animal requirement in the maintenance state. Moreover, this study tried to emphasize the necessity of recognizing the anti-quality features of forage (including essential oil compound, the amount of alkaloids, toxic glycosides, etc.) for managing human and animal food by means of answering to the question that why the studied species is less considered by the animal or sometimes cause severe poisoning in animals.

\section{Materials and Methods}

In the present study, chemical compounds of different thyme species were identified. The species (Thymus kotschyanus, Thymus fedtschenkoi, Thymus daenensis, and Thymus transcaspicus) were those specified as pasture species and whose essential oil have high pharmaceutical and industrial value, and are among the exported cultivars of Iran. Moreover, they were identified in 10 mountainous regions of Iran (Sahand, Ghare Dagh, Firuzkuh, Karsang, Badamestan, Saral, Sar Ali Abad, Taleghan, Kajur in Mazandaran, and Nazlu in Urmia) that were introduced as vegetation areas of Iran and Toran [8] (Table 1). Therefore, samples were taken from the mentioned species at three growth stages (vegetative growth, flowering, and seed ripening). Afterwards, the percentage of crude protein and amount of the metabolic energy was determined by measuring the nitrogen and acid detergent fiber (ADF) of the species in the laboratory for determining the daily animal requirement. In addition, the chemical compounds of their essential oil were presented since those compounds contain important medicinal and nutritional properties that can be employed in human nutrition with reference to the research conducted in different climate regions of Iran.

\section{Results}

The results obtained from the conducted studies in different climate regions of Iran indicate that different growth stages have significant effects on the chemical compounds. The amount of crude protein and metabolic energy is reduced with the advance of the growth stages (Table 2). The highest amount of crude protein (15.58\%) belongs to the vegetative growth stage of the Thymus fedtschenkoi species in Firuzkuh region and the least amount (5.29\%) was related to the seed-ripening stage of the Thymus kotschyanus species in the pastures of Taleghan area. The highest amount of metabolic energy (10.03 megajoules per kilogram of dry matter) is related to the vegetative growth stage of Thymus kotschyanus species on pastures of Saral in kordestan and the least amount (5.39 megajoules per kilogram of dry matter) belongs to the seed-ripening stage of Thymus transcaspicus on pastures of Sar Ali Abad in Gorgan.

The trend of changes for the different species of thyme essential oil at different growth stages was generally opposite of the trend of changes of crude protein and metabolic energy amounts. Investigating the mentioned trend demonstrates that this plant (herb) has less essential oil at vegetative growth stage; however, its essential oil increased dramatically after getting to the flowering stage and, finally, after completion of the growth and end of flowering stage the amount of essential oil decreases. The amount of this reduction varies according to environmental factors at different climate regions. Three compounds, namely linalool (1.8-60.4\%), geraniol (0.1-50.5\%), and thymol (1.6-58.4\%), are usually found more than other compounds in essential oil of various thyme species [9]. In addition, the average yield of essential oil production by the flowering tops of thyme according to the dry matter varies in different climate zones and its amount is higher than other medicinal herbs in other parts of the world and Iran [7].

\section{Conclusion}

On the basis of achieved results, crude protein and metabolic energy

\begin{tabular}{|c|c|c|c|c|c|c|c|c|c|}
\hline \multirow{2}{*}{ Region } & \multirow{2}{*}{ Province } & \multicolumn{2}{|c|}{ Geographic coordinates } & \multirow{2}{*}{$\begin{array}{l}\text { Altitude } \\
\text { (m) }\end{array}$} & \multirow{2}{*}{$\begin{array}{l}\text { Average Annual } \\
\text { Rainfall } \\
(\mathrm{mm})\end{array}$} & \multirow{2}{*}{$\begin{array}{l}\text { Climate } \\
\text { (Ambroje } \\
\text { classification) }\end{array}$} & \multirow{2}{*}{$\begin{array}{l}\text { Vegetative } \\
\text { climate }\end{array}$} & \multirow{2}{*}{$\begin{array}{l}\text { Vegetative } \\
\text { region }\end{array}$} & \multirow{2}{*}{$\begin{array}{l}\text { Pasture } \\
\text { type }\end{array}$} \\
\hline & & Longitude & Latitude & & & & & & \\
\hline Sahand & East Azarbaijan & $37^{\circ} 44^{\prime} 27^{\prime \prime}$ & $46^{\circ} 20^{\prime} 2^{\prime \prime}$ & $3000-3400$ & 326 & Cold highlands & $\begin{array}{l}\text { Azerbaijani } \\
\text { vegetations }\end{array}$ & Semi-steppe & summer \\
\hline $\begin{array}{l}\text { Ghare } \\
\text { Bagh }\end{array}$ & West Azarbaijan & $38^{\circ} 3^{\prime} 23^{\prime \prime}$ & $48^{\circ} 0^{\prime} 11^{\prime \prime}$ & $1800-2100$ & 390 & Cold and semi-humid & $\begin{array}{l}\text { Azerbaijani } \\
\text { vegetation }\end{array}$ & Semi-steppe & midpoint \\
\hline $\begin{array}{l}\text { Nazlu region } \\
\text { of Urmia }\end{array}$ & West Azarbaijan & $\begin{array}{l}37^{\circ} 41^{\prime} 18^{\prime \prime}- \\
37^{\circ} 50^{\prime} 42^{\prime \prime}\end{array}$ & $\begin{array}{l}44^{\circ} 57^{\prime} 4^{\prime \prime} \\
-45^{\circ}\end{array}$ & $1900-3000$ & 700 & Very humid cold & $\begin{array}{l}\text { Azerbaijani } \\
\text { vegetation }\end{array}$ & Semi-steppe & summer \\
\hline Firuzkuh & Tehran & $35^{\circ} 52^{\prime} 60^{\prime \prime}$ & $52^{\circ} 36^{\prime} 6^{\prime \prime}$ & $2000-2800$ & 595 & Cold highlands & $\begin{array}{l}\text { Alborz } \\
\text { vegetation }\end{array}$ & Semi-steppe & summer \\
\hline Taleghan & Tehran & $\begin{array}{l}36^{\circ} 10^{\prime} 4^{\prime \prime}-36^{\circ} \\
1^{\prime} 58^{\prime \prime}\end{array}$ & $\begin{array}{l}50^{\circ} 44^{\prime} 18^{\prime \prime}- \\
50^{\circ} 34^{\prime} 30^{\prime \prime}\end{array}$ & $1800-4400$ & 600 & $\begin{array}{l}\text { Very humid cold and } \\
\text { cold highlands }\end{array}$ & $\begin{array}{l}\text { Alborz } \\
\text { vegetation }\end{array}$ & Semi-steppe & summer \\
\hline Karsang & $\begin{array}{l}\text { Chahar Mahel-e- } \\
\text { Bakhtiari }\end{array}$ & $32^{\circ} 31^{\prime} 32^{\prime \prime}$ & $50^{\circ} 28^{\prime} 35^{\prime \prime}$ & $2250-3100$ & 332 & Cold highlands & $\begin{array}{l}\text { Vegetation of } \\
\text { East Zagros }\end{array}$ & Semi-steppe & summer \\
\hline Badames-tan & Znjan & $36^{\circ} 45^{\prime} 36^{\prime \prime}$ & $48^{\circ} 48^{\prime} 21^{\prime \prime}$ & $1800-2400$ & 487 & Cold and semi-humid & $\begin{array}{l}\text { Central Iran } \\
\text { vegetation }\end{array}$ & Semi-steppe & midpoint \\
\hline Saral & Kordestan & $35^{\circ} 32^{\prime} 48^{\prime \prime}$ & $46^{\circ} 47^{\prime} 35^{\prime \prime}$ & $1900-2300$ & 470 & Cold and semi-humid & $\begin{array}{l}\text { Vegetation of } \\
\text { East Zagros }\end{array}$ & Semi-steppe & summer \\
\hline Sar Ali Abad & Gholestan & $36^{\circ} 39^{\prime}$ & $54^{\circ} 32^{\prime}$ & $2200-2900$ & 348 & Cold highlands & $\begin{array}{l}\text { Vegetation of } \\
\text { North Khorasan }\end{array}$ & Semi-steppe & summer \\
\hline $\begin{array}{l}\text { Kajur in } \\
\text { Mazan-daran }\end{array}$ & Mazanderan & $36^{\circ} 20^{\prime}-36^{\circ} 19^{\prime}$ & $\begin{array}{l}51^{\circ} 45^{\prime}-51^{\circ} \\
44^{\prime}\end{array}$ & $2100-2700$ & 650 & Very humid and cold & $\begin{array}{l}\text { Alborz } \\
\text { vegetation }\end{array}$ & Semi-steppe & summer \\
\hline
\end{tabular}

Table 1: Specification of studied areas in Irani and Torani regions. 
Citation: Arzani H, Motamedi, Arzani (2013) Chemical Compounds of Thyme as a Medicinal Herb in the Mountainous Areas of Iran. J Nutr Disorders Ther S12: 003. doi:10.4172/2161-0509.S12-003

Page 3 of 4

\begin{tabular}{|c|c|c|c|c|}
\hline Region & Species & Growth stage & Crude protein percentage & $\begin{array}{l}\text { Metabolic energy value } \\
\text { (megajoules per kilogram of dry matter) }\end{array}$ \\
\hline \multirow{3}{*}{ Sahand } & \multirow{3}{*}{ Thymus kotschyanus } & Vegetative & $8.95 \pm 0.08 d$ & $7.81 \pm 0.05 c$ \\
\hline & & flowering & $8.43 \pm 0.09 d$ & $7.06 \pm 0.11 \mathrm{~d}$ \\
\hline & & seeding & $7.85 \pm 0.07 \mathrm{~d}$ & $6.49 \pm 0.11 \mathrm{~d}$ \\
\hline \multirow{3}{*}{ Gharebagh } & \multirow{3}{*}{ Thymus kotschyanus } & Vegetative & $14.43 \pm 0.16 a$ & $8.87 \pm 0.25 b$ \\
\hline & & flowering & $9.77 \pm 0.65 c$ & $7.05 \pm 0.33 d$ \\
\hline & & seeding & $6.20 \pm 0.30 \mathrm{e}$ & $5.70 \pm 0.32 \mathrm{e}$ \\
\hline \multirow{3}{*}{ Nazlu area in Urmia } & \multirow{3}{*}{ Thymus kotschyanus } & Vegetative & - & - \\
\hline & & flowering & $10.30 \pm 0.15 c$ & $7.69 \pm 0.03 c$ \\
\hline & & seeding & $8.52 \pm 0.29 d$ & $7.23 \pm 0.02 d$ \\
\hline \multirow{3}{*}{ Firuzkuh } & \multirow{3}{*}{ Thymus fedtschenkoi } & Vegetative & $18.58 \pm 0.99 a$ & $10.10 \pm 0.12 a$ \\
\hline & & flowering & $13.47 \pm 0.59 b$ & $8.43 \pm 0.09 b$ \\
\hline & & seeding & $9.86 \pm 0.53 \mathrm{c}$ & $7.64 \pm 0.25 c$ \\
\hline \multirow{3}{*}{ Taleghan } & \multirow{3}{*}{ Thymus kotschyanus } & Vegetative & $9.94 \pm 1.11 \mathrm{c}$ & $8.76 \pm 0.08 b$ \\
\hline & & flowering & $6.00 \pm 0.17 e$ & $7.70 \pm 0.07 c$ \\
\hline & & seeding & $5.29 \pm 1.01 \mathrm{e}$ & $6.89 \pm 0.11 d$ \\
\hline \multirow{3}{*}{ Karsang } & \multirow{3}{*}{ Thymus daenensis } & Vegetative & $15.29 \pm 0.61 \mathrm{a}$ & $10.02 \pm 0.17 \mathrm{a}$ \\
\hline & & flowering & $8.90 \pm 0.64 \mathrm{~d}$ & $7.69 \pm 0.37 d$ \\
\hline & & seeding & $5.24 \pm 0.42 \mathrm{e}$ & $5.81 \pm 0.30 \mathrm{e}$ \\
\hline \multirow{3}{*}{ Badamestan } & \multirow{3}{*}{ Thymus kotschyanus } & Vegetative & $11.91 \pm 0.33 b$ & $8.51 \pm 0.14 b$ \\
\hline & & flowering & $9.31 \pm 1.01 \mathrm{~d}$ & $7.57 \pm 0.11 \mathrm{c}$ \\
\hline & & seeding & $7.38 \pm 0.19 d$ & $6.47 \pm 0.11 \mathrm{~d}$ \\
\hline \multirow{3}{*}{ Saral } & \multirow{3}{*}{ Thymus kotschyanus } & Vegetative & $15.81 \pm 1.35 \mathrm{a}$ & $10.03 \pm 0.42 \mathrm{a}$ \\
\hline & & flowering & $8.74 \pm 0.67 d$ & $7.75 \pm 0.42 c$ \\
\hline & & seeding & $6.53 \pm 0.31 e$ & $6.58 \pm 0.47 d$ \\
\hline \multirow{3}{*}{ Sar Ali Abad } & \multirow{3}{*}{ Thymus transcaspicus } & Vegetative & $12.61 \pm 0.60 b$ & $8.44 \pm 0.30 b$ \\
\hline & & flowering & $10.44 \pm 0.29 c$ & $7.41 \pm 0.30 \mathrm{~d}$ \\
\hline & & seeding & $7.34 \pm 0.06 \mathrm{~d}$ & $5.39 \pm 0.07 e$ \\
\hline \multirow{3}{*}{ Kajur area in Mazandaran } & \multirow{3}{*}{ Thymus kotschyanus } & Vegetative & $11.82 \pm 0.05 b$ & $8.43 \pm 0.02 b$ \\
\hline & & flowering & $9.82 \pm 0.22 c$ & $7.58 \pm 0.01 c$ \\
\hline & & seeding & $7.88 \pm 0.27 d$ & $7.13 \pm 0.01 d$ \\
\hline
\end{tabular}

$a, b, c$, and ... indicate a significant difference between the mean values of the quality indices of forage species in different regions

Table 2: Crude protein and metabolic energy values of different species of Thyme in different climate zones of Iran.

values of thyme species at initial growth stages (vegetative growth and flowering) per unit weight of vegetation of the studied areas was more than $7 \%$ and $8 \mathrm{MJ} / \mathrm{Kg}$, respectively. However, at final growth stages, crude protein and metabolic energy values were less than the critical level of mentioned indices ( $7 \%$ and $8 \mathrm{MJ} / \mathrm{Kg}$, respectively) for grazing of animal unit. Therefore, thyme species are optimal for grazing animal on the pasture at initial growth stages (vegetative growth), but they are less appropriate for the grazing animal as the growth stages progress towards the flowering stage since the essential oil and the chemical compounds within this oil increases, despite the fact that thyme species have a high percentage of crude protein and metabolic energy. As a result, these species remain on the pasture without being grazed and can be used for both human and animal nutrition with the management strategies and utilization of pastures in line with the multipurpose use as well as consideration of the total productive functions of the ecosystem $[10,11]$.

At this time of the grazing season that coincides with late June and early July at different climate zones, local farmers harvest the flowering tops of thyme species in their allotments in the form of rural and nomadic cooperatives. In recent years, beneficial measures regarding the way of harvesting, determining the time of harvest, identifying the production rate per unit area, exploring the essential oil changes of the medicinal and industrial species at different growth stages and determining their economic value in comparison with other applications, goods and services of forest and pasture ecosystems have been taken by the forming the Utilizing By-Products Office in the
Forests, Range and Watershed Organization (FRWO) and forming the headquarters of research, medicinal plants' use, and Iranian medicine development in presidential department of technology. Such measures have caused the weight and importance of natural resources to be enhanced in the annual budgeting and development programs of Iran and further importance to be considered for the natural resources domain. In this regard, System of Environmental Economics Accounting has been emphasized by the related organizations instead of the System of National Accounts.

\section{References}

1. Zargari A (1993) Medicinal Herbs, $4^{\text {th }}$ edition, Tehran University Publications, 923.

2. Ghahreman A (1994) Cormophytes of Iran, $3^{\text {rd }}$ edition, Tehran University Publicaations, 867

3. Jamzad Z (2009) Thymes and Savories of Iran, Research Institute of Forests and Rangelands Publications, 15

4. Asgari F, Sefidkon F, Mirza M (2003) The quantitative and qualitative comparison of Thymus pubescens essential oil in various vegetation areas of Tehran province. Iranian Journal of Medical and Aromatic Plants 19: 125-136.

5. Sajjadi SE, Khatamsaz M (2003) Composition of the essential oil of Thymus daenesis Celak and Thymus lancifolius (Celak) Jalas. Journal of Essential Oil Research, 15: 34-45.

6. Barazandeh M M, Bagherzade K (2007) Investigating the chemical compounds of essential oil of Thymus daenesis collected from four different areas of Esfahan province. Journal of Medicinal Plants, 23: 15-19.

7. Yavari AR, Nazeri V, Sefidkon F, Hasani MA (2010) Investigating the chemical 
compounds of Thymus migricus essential oil in different vegetation areas of West Azerbaijan province. Iranian Journal of Medicinal and Aromatic Plants Research 26: 14-21.

8. Farahpur M, Fayyaz M, Ghasriani F, Akbarzade M (2011) Determining the harvestable forage from country rangelands national project report. Research Institute of Forests and Rangelands Publications.

9. Sefidkon F, Kalvandi R, Atri M, Barazandeh MM (2005) Essential oil variability of Thymus eriocalyx (Ronninger) Jalas. Flavour and Fragrance Journal 20 $521-524$.

10. Arzani H (2009) Forage quality and daily requirement of grazing animal, University of Tehran, 354.

11. Arzani H, Motamedi J, Zare Chahoki MA (2010) Report of national project Forage quality of range species in Iran, Organization of Forests, Rangelands and Watershed Management of Iran 230. 